\title{
Nutritional Status Among Elderly in Ambulatory Care Setting
}

\author{
Karina Nurizky, ${ }^{1}$ Putri Teesa, ${ }^{2}$ Muhammad Apandi ${ }^{3}$ \\ ${ }^{1}$ Faculty of Medicine, Universitas Padjadjaran, ${ }^{2}$ Departmen of Anatomy, Cell Biology and \\ Physiology Faculty of Medicine Universitas Padjadjaran, ${ }^{3}$ Department of Internal Medicine, \\ Faculty of Medicine Universitas Padjadjaran/Dr. Hasan Sadikin General Hospital Bandung
}

\begin{abstract}
Background: Nutritional status is a final outcome from a balance between food intake and body's needs of the nutrients. Elderly is people whose age more than 60 years old. In Indonesia, elderly population has increased. Its phenomena is also known as population aging. Population aging is related to malnutrition in elderly. Malnutrition is defined as the insufficient, excessive or imbalanced consumption of nutrients.The objective of this study was to describe the nutritional status among elderly outpatients in geriatrics clinic of Dr. Hasan Sadikin General Hospital Bandung.
\end{abstract}

Methods: This study was a descriptive cross-sectional study that used primary data in geriatrics clinic Dr. Hasan Sadikin General Hospital Bandung from September 2013 to October 2013. The sampling method was convenience sampling. This study was done with 43 elderly (women, $n=27$ and men, $n=16$ ) outpatients. The nutritional status was classified by the questionnaire of Mini Nutritional Assessment into malnourished, risk of malnutrition and without malnutrition (adequate). After collecting the data, it was analyzed by Microsoft Excel in presenting the proportion of the elderly nutritional status.

Results: Among all the respondents, 27 (63\%) respondents had adequate nutrition and 16 (37\%) respondents had risk of malnutrition. There was no respondent who had malnutrition (undernutrition).

Conclusions: Majority of elderly outpatients in geriatrics clinic Dr. Hasan Sadikin General Hospital had adequate nutrition.

Keywords: Aging, elderly, malnutrition, nutritional status

\section{Introduction}

In recent years, the elderly population in the world population has increased rapidly. Elderly people means people who grow older, increasing the numbers and proportions of the very old. ${ }^{1}$ This phenomena happened because of decreasing of the fertility rate, improvement of health status caused by technology and medical research progress, epidemiologic transition from infection disease to degenerative disease, improvement of nutritional status characterized by increasing obesity in elderly, increasing life expectancy, and alteration of lifestyle from urban rural lifestyle to sedentary urban lifestyle. ${ }^{2}$

The increasing elderly population will affect their life aspects through physical, biological, psychological, and social changes or degenerative disease caused by aging.
Naturally, increasing age is in line with the decreasing physiologic function in elderly. These physiological changes could cause a decrease in food intake cause the decrease of nutritional status. This problem is one of malnutrition cases. ${ }^{2}$

Malnutrition is a condition of deficiency, overabundance, or imbalance of energy, protein, and other nutrients causing a side effect on body, body function, and disease. ${ }^{3}$ Risk factors of malnutrition are disease, difficulty in eating, teeth loss, economic problems, social isolation, over consumption of drugs and dependence when eating. ${ }^{4}$

The increasing of elderly population is related to geriatrics syndromes. One of them is malnutrition. Malnutrition makes elderly susceptible with infection and diseases.

Mini Nutritional Assessment (MNA) has been used to identify risk of malnutrition in the elderly. Mini nutritional assessment is a

Correspondence: Karina Nurizky, Faculty of Medicine, Universitas Padjadjaran, Jalan Raya Bandung-Sumedang Km. 21, Jatinangor, Sumedang, West Java, Indonesia, Phone: +6281313969390 Email: karinanurizky@gmail.com 
validated tool with positive predictive value $97 \%$ to detect undernutrition in elderly. It has $96 \%$ sensitivity and $98 \%$ specificity. ${ }^{5}$

The MNA is simple, low cost and noninvasive method that can be done at bedside. ${ }^{5}$ At this period of time, based on former exploring research document, the study about nutritional status of the elderly in Dr. Hasan Sadikin General Hospital Bandung will be the first academic research, which is able to expanding the knowledge and related information about the elderly problems. Thus, this study was conducted to describe the nutritional status among elderly outpatients in geriatrics clinic of Dr. Hasan Sadikin General Hospital Bandung.

\section{Methods}

This study was conducted in SeptemberOctober 2013 at geriatrics clinic, Dr. Hasan Sadikin General Hospital Bandung, West Java. The subjects were elderly aged more than 60 years old, who visited the clinic, regarding to whether they were newly-coming patients or the patients with follow-up purpose, and ready to participate by filling the informed consent. In this study, with the proportion of $50 \%$, $95 \%$ confidence interval, and $15 \%$ precision, minimum sample required is 43 . From these criteria, 43 elderly participated and selected by convenience sampling.

Cross sectional descriptive quantitative type of study was conducted since through this type of study.The nutritional status can be obtained in one time visit. The purpose of this study had been approved and legalized by Health Research Ethics Committee of Dr. Hasan Sadikin Hospital.

The patients filled the MNA questionnaire that consist of two forms, short form MNA for screening and long form MNA for assessment. Short form MNA has 6 questions include declining food intake, weight loss, mobility, psychology stress or acute disease, neuropsychological problems and body mass index. Long form MNA has 12 questions include independence, drugs consumption, ulcus decubitus, frequency of full meals, protein intake, fruits and vegetables consumption, fluid intake, mode of feeding, self view about their nutritional status, patient's perspective about their healthy status, mid-arm circumference and calf circumference. ${ }^{6}$ Each question in MNA has score that would be calculated and classified. The classifications were malnourished (total score <17), at risk of malnutrition (total score 17-23,5), and without malnutrition or adequate nutrition (total score $\geq 24$ ). After

Table 1 General Characteristics of the Respondents

\begin{tabular}{lcc}
\hline \multicolumn{1}{c}{ Characteristics } & Total $(\mathbf{n}=\mathbf{4 3})$ & Percentage (\%) \\
\hline Sex & & \\
$\quad$ Female & 27 & 63 \\
$\quad$ Male & 16 & 37 \\
Age (Years old) & & \\
$60-64$ & 2 & 5 \\
$65-70$ & 10 & 23 \\
$>70$ & 31 & 72 \\
Education & & \\
Elementary School & 4 & 9 \\
Junior High School & 4 & 98 \\
Senior High School & 25 & 24 \\
Academy / University & 10 & 58 \\
Job & & 9 \\
Retirement & 25 & 33 \\
No Retirement & 4 & \\
Housewife & 14 & \\
\hline
\end{tabular}


Table 2 Elderly Distribution Based on Nutritional Status Using Mini Nutritional Assessment (MNA) , $2013(n=43)$

\begin{tabular}{llcc}
\multicolumn{1}{c}{\begin{tabular}{c}
\multicolumn{1}{c}{$\begin{array}{c}\text { Short form } \\
\text { (Screening) MNA }\end{array}$} \\
(Assessment) MNA
\end{tabular}} & $\begin{array}{c}\text { Fong form } \\
\text { (A) }\end{array}$ & $\begin{array}{c}\text { Percentage } \\
\text { (\%) }\end{array}$ \\
\hline $\begin{array}{l}\text { Normal and do not need to fulfill long form MNA } \\
\text { At risk of malnutrition and need to fulfill long }\end{array}$ & Normal & 6 & 49 \\
form MNA & At risk of Malnutrition & 16 & 14 \\
& Malnutrition & 0 & 37 \\
\hline
\end{tabular}

Note: MNA = Mini nutritional assessment

the data were collected, it was analyzed using Microsoft Excel in presenting the proportion of the elderly nutritional status.

\section{Results}

Overall, the study was carried out in 43 elderly outpatients of Geriatric Clinic that fulfill the inclusion criteria. In this study, the subject characteristic was differ in sex, age, education level and job (Table 1).
Out of 43 respondents, 21 (49\%) respondents had normal nutrition and did not need to fulfill long form MNA, and the rest, $22(51 \%)$ respondents were at risk of malnutrition and need to fulfill long form MNA.

Female elderly had higher risk of malnutrition. People whose age are more than 70 years old had higher risk of malnutrition. Elderly with lower education also had higher risk of malnutrition. It showed that housewife had higher risk of malnutrition (Table 3 ).

Female elderly had higher risk of

Table 3 Distribution of Elderly Nutritional Status Using Short Form Mini Nutritional Assessment (MNA)

\begin{tabular}{|c|c|c|c|c|}
\hline & \multicolumn{4}{|c|}{ Screening Result } \\
\hline & \multicolumn{2}{|c|}{$\begin{array}{l}\text { Normal and do not need to } \\
\text { fulfill long form MNA }\end{array}$} & \multicolumn{2}{|c|}{$\begin{array}{l}\text { At risk of malnutrition and } \\
\text { need to fulfill long form MNA }\end{array}$} \\
\hline & Frequency & Percentage (\%) & Frequency & Percentage $(\%)$ \\
\hline \multicolumn{5}{|l|}{ Sex } \\
\hline Male & 10 & 63 & 6 & 37 \\
\hline Female & 11 & 41 & 16 & 59 \\
\hline \multicolumn{5}{|l|}{ Age (Years old) } \\
\hline $60-64$ & 2 & 100 & 0 & - \\
\hline $65-70$ & 5 & 50 & 5 & 50 \\
\hline$>70$ & 14 & 45 & 17 & 55 \\
\hline \multicolumn{5}{|l|}{ Education } \\
\hline Elementary School & 0 & 0 & 4 & 100 \\
\hline Junior High School & 1 & 25 & 3 & 75 \\
\hline Senior High School & 13 & 52 & 12 & 48 \\
\hline Academy/University & 7 & 70 & 3 & 30 \\
\hline \multicolumn{5}{|l|}{ Occupation } \\
\hline Retirement & 12 & 48 & 13 & 52 \\
\hline No retirement & 3 & 75 & 1 & 25 \\
\hline Housewife & 6 & 43 & 8 & 57 \\
\hline
\end{tabular}


Table 4 Distribution of Elderly Nutritional Status Using Long Form Mini Nutritional Assessment (MNA

\begin{tabular}{|c|c|c|c|c|}
\hline \multirow{3}{*}{ Characteristics } & \multicolumn{4}{|c|}{ Assessment Result } \\
\hline & \multicolumn{2}{|c|}{ Normal } & \multicolumn{2}{|c|}{ At risk of malnutrition } \\
\hline & Frequency & Percentage (\%) & Frequency & Percentage (\%) \\
\hline \multicolumn{5}{|l|}{ Sex } \\
\hline Male & 2 & 33 & 4 & 67 \\
\hline Female & 4 & 25 & 12 & 75 \\
\hline \multicolumn{5}{|l|}{ Age (Years old) } \\
\hline $60-64$ & 0 & 0 & 0 & 0 \\
\hline $65-70$ & 3 & 50 & 3 & 50 \\
\hline$>70$ & 2 & 12 & 14 & 88 \\
\hline \multicolumn{5}{|l|}{ Education } \\
\hline Elementary School & 1 & 25 & 3 & 75 \\
\hline Junior High School & 0 & 0 & 3 & 100 \\
\hline Senior High School & 4 & 33 & 8 & 67 \\
\hline Academy/University & 1 & 33 & 2 & 67 \\
\hline \multicolumn{5}{|l|}{ Occupation } \\
\hline Retirement & 4 & 31 & 9 & 69 \\
\hline No retirement & 1 & 100 & 0 & 0 \\
\hline Housewife & 1 & 12 & 7 & 88 \\
\hline
\end{tabular}

malnutrition. Elderly whose age is more than 70 years old had higher risk of malnutrition. Elderly with lower education had higher risk of malnutrition. Housewife had higher risk of malnutrition (Table 4).

Most of elderly in Geriatrics Clinic Hasan Sadikin General Hospital Bandung were in adequate nutrition. There were not found malnutrition in this study (Table 5).

\section{Discussion}

According to this study, majority of the respondents were in normal (adequate) nutrition. Study established in 2011 at Brazil ${ }^{7}$ reported that majority of the respondents, $56 \%$ respondents were at risk of malnutrition, $36.1 \%$ respondents was in adequate nutrition and $8.3 \%$ respondents were malnutrition. In other study conducted by Oliveira et $\mathrm{al}^{8}$ in Brazil, it presented $37.1 \%$ respondents were at risk of malnutrition, $33.8 \%$ respondents had adequate nutrition, and $29.1 \%$ respondents were malnourished. In other study conducted in Makkah Governorate9, it was reported $57.8 \%$ were at risk of malnutrition, $22.6 \%$ were malnutrition and $19.6 \%$ respondents were in adequate nutrition. This difference findings in this studywith former study might be caused by differences in subject of study. This study subjects were elderly outpatients in geriatrics clinic of Dr. Hasan Sadikin General Hospital, whereas in other studies, the study subjects were elderly in healthy condition, institutionalized elderly and hospitalized elderly.

Table 5 Distribution of Elderly Nutritional Status Using Full form Mini Nutritional Assessment (MNA)

\begin{tabular}{lcc}
\hline \multicolumn{1}{c}{ Nutritional Status } & Frequency & Percentage \\
\hline Normal (Adequate) & 27 & $63 \%$ \\
At Risk of Malnutrition & 16 & $37 \%$ \\
\hline
\end{tabular}


In this study, it was reported that female elderly were predominantly had the risk of malnutrition, while male elderly predominantly had adequate nutrition. It strengthens the findings in a study conducted in Brazil ${ }^{7}$. It is reported that female elderly have higher tendency to have risk of malnutrition. It might happened because of the subject of this study predominantly were female elderly.

According to this study, prevalence of respondents who have risk of malnutrition is higher in elderly age more than 70 years old. It strengthens the study conducted by Donini et al. ${ }^{10}$ that malnutrition associated with increasing age. It might be caused by the changes in the body composition ofelderly that influences the nutritional status. ${ }^{11}$ It was reported that in the elderly there is declining in food intake and motivation to eat. It might cause more problems associated with the regulation of energy balance and the control of food intake and it would affect the nutritional status. ${ }^{12}$

In this study, it is reported that there is a tendency for having risk of malnutrition in line with lower education. It strengthens the result in the study conducted by Virtuoso et al. ${ }^{12}$ it is reported that the illiterate elderly women had a higher prevalence of malnutrition compared to those with education. A higher level of education was possibly associated with higher income and better lifestyle, which in turn resulted in a better nutritional status in elderly.12

This study has limitations such as, due to the constraints of time and resources, and the lack of information about nutrition intake per day on respondents, which result in several missing characteristics data. Respondents of this study are elderly aged more than 60 years old, and questionnaires were used to collect the data, so there is a tendency for a recall bias. Further research is needed to improve this limitation and broaden the scope.

In conclusion, most of elderly patients in geriatric clinic Hasan Sadikin Bandung are in adequate nutrition. However, there is still a tendency of the patient to have risk of malnutrition. Based on consideration, this case can be mitigated by the family care and social environment.

Intervention is needed to reduce the risk of malnutrition. One of the intervention is by giving more information about risk of malnutrition and the impacts of malnutrition for patients and family as the caregiver of elderly.

\section{References}

1. Fatmah. Gizi usia lanjut. Jakarta: Erlangga; 2010.

2. United Nations Population Fund (UNFPA). Aging in the twenty-first century: a celebration and a challenge. New York: UNFPA and HelpAge International; 2012.

3. Harris D, Haboubi N. Malnutrition screening in the elderly population. J R Soc Med. 2005;98(9):411-4.

4. Whitney EN, Rolfes SR. Understanding nutrition. 10th ed. Belmont: Thomson Wadsworth; 2005.

5. Drescher T, Singler K, Ulrich A, Koller M, Keller U, Christ-Cralin M, et al. Comparison of two malnutrition risk screening methods (MNA and NRS 2002) and their association with markers of protein malnutrition in geriatric hospitalized patients. Eur J Clin Nutr. 2010; 64:887-93.

6. Guigoz Y. The mini nutritional assessment (MNA) review of the literature : what does it tell us? J Nutr Health Aging. 2006;10(6):466-85

7. Machado RSP, Coelho SC. Risk of malnutrition among Brazilian institutionalized elderly: a study with the mini nutritional assessment (MNA) questionnaire. J Nutr Health Aging. 2011;15(7):532-5.

8. Oliveira MRM, Fogaca KCP, Leandro-Merhi VA. Nutritional status and functional capacity of hospitalized elderly. Nutrition Journal. 2009;8:54.

9. Elmadbouly MA, Abd Elhafez AM. Assessment of Nutritional Status of Hospitalized Elderly Patients in Makkah Governate. Pak J Nutr. 2012;11(10):88692.

10. Donini LM, Savina C, Cannella C. Eating habits and appetite control in the elderly: the anorexia of aging. Int Psychogeriatr. 2003;15(1):73-87.

11. Hickson M. Malnutrition and ageing. Postgrad Med J. 2006;82(963):2-8.

12. Virtuoso-Júnior JS, Tribess $S$, Romo-Perez $\mathrm{V}$, Oliveira-Guerra R. Factors associated to risk of malnutrition amongst elderly women in low-income communities. Colombia Médica . 2012;43(1):54-620. 